\title{
Foreign Direct Investment and Wage Spillovers in Indonesia
}

\author{
Sultoni ${ }^{a} *$ \\ ${ }^{a}$ The Australian National University, Canberra, Australia
}

\section{INFORMASI ARTIKEL}

\section{Article history:}

Date Submission: 09 December 2019

First revision: 04 August 2020

Accepted: 11 August 2020

Available online: 25 August 2020

Keywords: foreign direct investment (FDI), horizontal wage spillover, vertical wage spillover

\begin{abstract}
This paper investigates the effect of Foreign Direct Investment (FDI) inflows on wage level paid by private domestic firms in Indonesia's manufacturing sector. The previous literature focuses on horizontal linkages only. We develop this study by examining the spillover through horizontal and vertical channels. We find that there is strong evidence of horizontal and vertical wage spillovers from foreign to local firms in Indonesian manufacturing. However, after controlling for some firm characteristics, which are technology intensity level and firm size, we find that although vertical wage spillovers exist irrespective of the firm characteristics, horizontal spillovers show different results. This spillover is not present in relatively low technology level firms.
\end{abstract}

\section{INTISARI}

Tulisan ini meneliti efek masuknya investasi asing langsung di Indonesia pada tingkat upah yang dibayarkan oleh perusahaan domestik swasta pada sektor manufaktur. Penelitian pada literatur sebelumnya hanya berfokus pada hubungan secara horizontal. Kami melakukan penelitian ini dengan memeriksa efek investasi langsung tersebut baik secara horizontal maupun vertikal. Kami menemukan terdapat bukti yang cukup kuat adanya efek perubahan tingkat upah secara horisontal maupun vertikal atas masuknya investasi asing di sektor manufaktur Indonesia. Dengan melihat beberapa karakteristik perusahaan, yakni tingkat intensitas teknologi dan ukuran perusahaan, ditemukan bahwa meskipun terdapat efek perubahan upah secara vertikal tanpa melihat karakteristik perusahaannya, efek secara horisontal menunjukkan hasil yang berbeda. Namun demikian, ffek perubahan ini tidak muncul pada perusahaan dengan tingkat teknologi yang relatif rendah.

2020 FIA UB. All rights reserved.

\section{Introduction}

Foreign direct investment (FDI) is considered as one of economic growth catalyst especially for developing countries (Gudaro et al., 2012, p. 22). FDI is also expected to give positive externalities for the host countries, such as an increase of domestic firm's productivity and a higher wage level for the employees.
Domestic firms potentially gain some advantages from the presence of multinational companies (MNCs) such as transfer of knowledge and technology (Newman et al., 2015, p. 168). Domestic workers can obtain benefits from training provided by MNCs or even enjoy higher wage rate. (Hoi \& Pomfret, 2010, p.159).

However, studies about FDI inflow and its impact on domestic wage conclude varying results. It is expected 
that the presence of multinational companies will increase the competition in labour market. MNCs are recognized to pay higher wages compared to domestic firms do. Tomohara \& Takii (2011, p. 512) and Lipsey \& Sjoholm (2004, p. 321) explain that given a similar size and characteristics, the wages paid by foreign firms are higher than the ones by domestic firms. Moreover, MNCs are also expected to become a learning model for domestic firms to increase their productivity. The raise in productivity should then induce local firms to pay higher wages than before.

Foreign enterprises entry can also force domestic firms to lower their scale of production. Local firms can decrease their productivity because they lose their market share due to foreign firm's presence as new competitors. If this demand effect on productivity decrease is material and persists consistently for long term, the technology and knowledge transfer from the MNCs will not improve net domestic firm's productivity. As a result, they must lower their wages. A study by Aitken \& Harrison (1999) provides an evidence of this situation. Although there is wage spillover in the USA manufactures, but FDI inflow in Mexico and Venezuela does not empirically give any wage spillover effect for local firms (Atiken \& Harrison, 1999, p. 369).

Lipsey \& Sjöholm (2004) have examined the wage spillover of FDI in Indonesia. They use data from Indonesia manufacture census data of 1996. Their analysis is focused on horizontal spillover due to an increasing competition on domestic labor market. By grouping workers into blue and white collar workers, they find that there is a significant wage spillover from FDI inflow in both workers. Similar studies are also conducted by Tomoharaa \& Takii (2011) and Driffield \& Girma (2000) with similar results. However, these studies focus on horizontal spillover only and do not examine the presence of wage spillover through vertical channel.

Using different approach, Hoi \& Pomfret (2010) examine wage spillovers of FDI inflow in Vietnam. They differentiate the wage spillover between horizontal and vertical spillover, incorporate firms and workers characteristics, and distinguish FDI by with and without training. They find that there is different effect of FDI inflow on domestic wages which depends on the domestic firm's characteristics. Furthermore, Pittiglio et al., (2012) also use similar method to examine wage spillover effect of Italy's FDI inflow. However, they find different result. Basically there is lack of wage spillovers effects of FDI inflow in Italy. But, wage spillover effect exists when considering technological gap. If the technology gap between foreign and local firm is large, foreign firm's presence leads to a positive horizontal spillover (higher wage paid by domestically owned firms in the same industry) and negative vertical spillover (lower wage paid by local firms in the different industry, upstream and downstream). Positive vertical spillover exists (higher wage paid by local firms in the different industry) when the technological gap is in medium size (Pittiglio et al., 2012, p. 25-26).

In the course of these varying results of existing studies, this paper aims to examine whether FDI inflow in Indonesia induces domestic manufacturing companies to pay higher wages. We develop the previous study by examining it through horizontal and vertical channel. In the other words, we will investigate whether there is any horizontal and vertical spillover of foreign firm's presence on the wages paid by Indonesia local firms.

\section{Theory}

The reason underlying the effort of a country to attract foreign investment is the potency to acquire modern technologies and new skills that the country does not possess. Spillovers from foreign to local firm does exist when the presence of multinational companies increases the productivity of domestic firms and the multinationals do not fully internalize this advantage (Javorcik, 2004, p. 607). This could take place when domestic firms are successful to increase their efficiency through imitating MNC affiliate's technologies through observation or employing skilled workers as trained by the multinationals. Moreover, spillover will also occur when the presence of foreign firm leads to more severe competition domestic market. The highly competitive market then force the locals to increase their efficiency or searching new technologies (Blomstrom \& Kokko, 1998, p. 3).

To simplify, spillover effect is considered as foreign firm's high performance and the adjustment made by domestic firms (Pham, 2009, p. 475). One of these spillovers is higher domestic wage rate. FDI may have effects on domestic wage horizontally and vertically. Horizontal wage spillover shows the degree of foreign penetration in each industry's labor market. It expresses the competing pressure from foreign companies that force local firms to increase their wage level. It begins with high wages paid by the multinationals to their employees. When these foreign firms compete together with the domestic firms in one labor market, the local firm will be forced to raise their wages to attract the expected workers. This situation will then lead to new higher wage equilibrium in the labour market. Furthermore, to keep their market share stable, the domestics will increase their efficiency which then increases their capacity to pay higher wage for their employees. Finally, there will be an increase of wage rate in the same sector and region.

Vertical spillover basically takes into account the interaction between foreign and local firms from across industries (inter-industry spillovers), through backward and forward linkages to input (Piyaareekul \& Peridy, 2010, p. 299). It comes from interaction process between 
foreign and domestic firms in different industries. This continuous contact will increase the productivity level of local firms. Theoretically, when they are connected in one supply chain and engaging in customers-suppliers relationship, technology and knowledge of foreign firms will excess to the domestic. Although foreign firms usually prevent transferring their knowledge to their competitors from the same industry, but they will tend to share it to their business partners from different industries for mutual benefits (Franco \& Kozovska, 2011, p. 127). Consequently, this partnership will induce an increase of local firm's productivity which then leads to an increase in the wage level paid to their employees.

\section{Research Method}

We construct the following model to estimate wage spillover horizontally and vertically. We adopt the model that is used by Hoi \& Pomfret (2010, pp. 160-162).

$$
\text { lnWage }_{i j t}=\beta_{1} \operatorname{HorS}_{j t}+\beta_{2} \operatorname{VerS}_{j t}+\beta_{3} X_{i j t}+N_{j}+P_{t}+R_{i}+\varepsilon_{i j t}
$$

In this model $\mathrm{i}, \mathrm{j}$ and $\mathrm{t}$ denote firm, industry and year. Wageijt represents average wage of local private firm $i$ in sector $\mathrm{j}$ and in year of $\mathrm{t}$. HorSjt is horizontal wage spillover affected by all MNCs in industry $\mathrm{j}$ and year $\mathrm{t}$, while VerSjt represents vertical wage spillover. Xijt represents a some of firm i's attributes that affect wage level. $\mathrm{Nj}, \mathrm{Pt}$ and $\mathrm{Ri}$ are dummy of fixed effects for industry, time dummies for aggregate shock and dummy for regional fixed effects, while eijt is random noise term.

Horizontal spillover, denoted as HorSjt, shows employment share of all foreign companies in industry $j$ where the firms operating their business. One channel of spillover comes from a higher competition in labour market due to the entry of multinational companies (Blomstrom \& Kokko, 1998, p. 2). More fierce competition forces the locals to increase their efficiency to survive. This then lead to a higher capacity of the locals to pay higher wages.

$$
\operatorname{HorS}_{j t}=\frac{\sum_{k=1}^{n} \operatorname{ForL}_{k j t}}{\sum_{k, i=1}^{n, m}\left(\text { ForL }_{k j t}+\operatorname{DomL}_{i j t}\right)}
$$

ForLkjt is employment from foreign manufacturing $\mathrm{k}$ in industry $\mathrm{j}$ and year $\mathrm{t}$, while DomLijt $(\mathrm{i}=1, \ldots, \mathrm{n})$ is local firms employment of company $i$ in industry $j$ and year $t$. The relationship of this variable with domestic firm wage is expected to be positive.

Furthermore, the potential impact of FDI on domestic wages might depend on geographical factor. This hypothesis is also examined by Lipsey \& Sjöholm (2004, p. 326) and Hoi \& Pomfret (2010, p. 164) in their studies. Workers tend to mobile among industries within one region, but not across different region. In this study, we will examine it by calculating an alternative measure of horizontal wage spillover, HorS-regional which indicates the share of foreign firm's employment in an industry within a particular province.

Vertical wage spillover comes from the interaction between local and foreign firms operating in different industries. This continuous relationship is expected to increase local firm's productivity so that they can pay higher wages for their employees. A productivity spillovers occur when local companies gain benefit from the foreign affiliate's superior knowledge of products, technologies or markets without bearing any cost that exhausts the whole benefits of the improvement (Blomstrom \& Kokko, 1998, p. 11). This spillover takes place through interaction between local and foreign firms in a supply chain relations where local firms supply intermediate inputs for the foreign (backward linkage) or the domestic firm act as the customer of intermediary products from the foreign (forward linkage).

VerSjt is a proxy for the input supplied by other industries representing the presence of foreign firms. It is intended to capture the extent of potential contacts between domestic firms with multinational suppliers.

$$
\operatorname{VerS} S_{j t}=\sum_{r=1}^{p} \delta_{j r t} * \operatorname{HorS}_{r t}(r=1, \ldots \ldots, p)
$$

The parameter $\delta$ jrt $(0 \leq \delta \leq 1)$ shows ratio of the output of industry $r$ that is used as the input in industry $j$. VerSjt is also expected to have a positive relationship with domestic firm wage.

Moreover, regarding firm's characteristics we construct some explanatory variables such as business scale, concentration level, intensity of capital, technology gap and labor skill. MNC's are widely known to operate their business using more capital-intensive, have larger scale, aim specific market and employ advanced technology and labor skill. All these factors are accounted for current wage differential between them with domestic firms.

To capture the impact of firms business scale on wage differential, we use a scale ratio obtained from dividing firm sales with the average sales of the industry.

$$
\text { Scale }_{i j t}=\left(\text { Sales }_{i t} / \text { AverageSales }_{j t}\right)
$$

This variable is expected to have positive relationship with domestic firm wages. The bigger firm's scale the higher wage they will pay for their workers.

Another factor is competition level in the industry. To get the value of this level, we use a proxy of Herfindahl index (known also as Herfindahl-Hirschman Index, HHI) that measures market concentration. The tightness of competition index is calculated as follow:

$$
H H I_{j t}=\sum_{i=1}^{n}\left(\frac{\text { Sales }_{i j t}}{\text { Sales }_{j t}}\right)^{2}(i=1, \ldots ., n)
$$


A high value of this index shows a high degree industry concentration. It means there is a less competition which gives an incentive to firm to pay lower wage. We expect there will be a negative relationship between this concentration indexes with domestic firm wage.

Another explanatory variable is capital intensity. It measures the ratio of capital value compared to the labor value used to produce goods or services. This ratio is calculated by dividing total fixed asset with total employment.

$$
\text { CapIntens }_{i j t}=\ln \left(\text { FixedAsset }_{i j t} / \text { Employment }_{i j t}\right)
$$

A high value of this ratio means firms use more capital rather than labor in their production, which then leads the firms to pay higher wages. So we also expect this ratio has positive relationship with the wage level.

Then, wage level is also influenced by firm's technological gap. Technology gap influences wages through labor productivity. The more productive the labor, the less technology gap will exist between domestic firms and the MNCs. It means local firms will pay higher wage due to more profit gained from higher productivity in their input factors. Technology gap index is calculated as follow:

$$
\begin{aligned}
& \text { TechnologyGap }_{i j t}=\left(\text { LaborProductivityForeign }_{j t}\right. \\
&\left.- \text { LaborProductivityDomestic }_{i j t}\right) \\
& / \text { LaborProductivityDomestic } \\
& i j t
\end{aligned}
$$

$$
\begin{aligned}
\text { TechnologyGap }_{i j t}= & \left(\frac{\text { AverageSales Foreign }_{j t}}{\text { AverageEmployment Foreign }_{j t}}\right. \\
& \left.-\frac{\text { Sales Domestic }_{i j t}}{\text { Employment Domestic }_{i j t}}\right) \\
& / \frac{\text { AverageSales Domestic }_{i j t}}{\text { AverageEmployment Domestic }}{ }_{i j t}
\end{aligned}
$$

If the gap is negative, it means that domestic firm $i$ is considered to be more productive than average foreign firms operates in that industry. Conversely, if the gap is positive it means that domestic firm $\mathrm{i}$ is less productive compared to the average MNCs operates in the same sector. Hence, this gap index is expected to have a negative relationship with the domestic firm wage level.

The last explanatory variable is labor skills. Worker's competency should affect the amount of wages they get. Skills or competency has high correlation with education. In this study, we will use education as proxy of labor skill. We will employ the logarithm value of school participation number. However, since the data of labor's skill for every single firm is not available, we will use school participation number of 19-24 years old in the province where the firm operates as the proxy.
Those models will be estimated using panel data estimation technique. To avoid any potential biases due to endogeneity problem comes from the tendency of foreign investment decision to invest on domestics with large business scale and having top performances (MNCs prefer to acquire the largest and the most profitable local firms), we restrict for the domestic private firms only. Another endogeneity problem can also exist due to the tendency of MNCs decision to locate their plants on region or industry with low wage rate. The estimated correlation between FDI inflow and the local firm's wage level could overestimate the real effect of the foreign sector. To solve this problem, we employ lagged values for the explanatory variables.

We employ the data from annual manufacturing industry survey conducted by Indonesia Statistics Center Board commonly known as Badan Pusat Statistik (BPS). This dataset provides information about some Indonesia manufacturings in every single year. The available information consists of individual firm's income, output, asset, capital, and expenses including wages. For this research, we will use the data of 2011 to 2014 surveys. The number of sample firms ranges from 13,869 firms in 2011 to 14,739 ones in 2014. However, after deleting for some missing and zero values, we get the usable data set which is a balanced panel data of 6,536 local firms and 577 foreign companies across 19 sectors. We do not employ 5 industries consisting of manufacturing of textiles, basic metals, machinery and equipment, motor vehicles, trailers and semi-trailers, and also furniture, due to the incompleteness of the data. All the variables are deflated into 2011 prices using consumer price index (CPI). To examine the level of vertical linkage index we also employ industrial input-output data from World Input-Output Database (WIOD). Finally, province level of school participation numbers obtained from BPS serve as the proxy of labour skill.

The industry is classified based on the two-digit level of Business Field Suitability Table provided by BPS. We use OECD standard to distinguish foreign and domestic firm, where firm with minimum 10 percent owned by foreigners will be categorized as foreign companies. We also group these sectors into low and medium \& high technology intensity based on United Nations Industrial Development (UNIDO) classification. Furthermore, we also divide the sample data into small \& medium enterprise and large company. We use BPS classification where firms with at least 100 workers will be categorized as large company.

Furthermore, the level of interaction between local and foreign firms across different industries is relatively high in the industry of fabricated metal products, except machinery and equipment, computer, electronic and optical products, and electrical equipment. The interaction degree is low in the sector of repair and 
installation of machinery and equipment, printing and reproduction of recorded media, and other transport equipment manufacturing. Finally, compared to the wage paid by the locals, the level of wage in multinational firms are higher in almost all industries, except in the industry of leather and related products, non-metallic mineral products, and other transport equipment manufactuing. By average, level wage of foreign firms is $29 \%$ higher than in local firms.

\section{Results and Discussion}

\subsection{Horizontal and Vertical Spillovers from Foreign Companies to Local Firm's Wage}

This part provides the results of examining the impact of FDI inflows on domestic firm's wage through horizontal and vertical linkages. The first column of table 1 shows that the coefficients of main variables (Horizontal and Vertical spillovers) are positive and significant. It means that FDI inflow positively correlates with the wage rate of local firms through both channel, horizontal and vertical spillover. Wage level of the locals tends to be higher in the industries where a large amount of foreign company exists. Higher inflow of FDI leads to higher wage rate paid by the domestics. In other words, the presence of multinational companies, which is associated to have high wage payment, has successfully induced the local companies to pay higher wages.

Competing in the same labour market within an industry, the high wage of foreign firm will put pressure on local firms to increase their wage rate to attract the targetted workers. To some extent, the entry of multinational companies will increase the demand on labour market in an industry. Taking an assumption that labour supply does not change, this up-shifting of demand curve will then form new higher wage equilibrium in the market. Furthermore, to keep the market share stable in more severe competition due to the entry of MNCs, the locals must increase their productivity and efficiency. Consequently, the locals will have more ability to pay higher wage, especially to grab the expected workers. These are the reasons underlying the significant and positive sign of Horizontal spillover variable. This result confirms the findings of Tomoharaa \& Takii (2011), Hoi \& Pomfret (2010), Lipsey \& Sjoholm (2004), and Driffield \& Girma (2000).

The presence of multinational companies might also increase the local's productivity through spillover of knowledge, technologies and skills. This spillover occurs through some degree of interactions between the multinationals and the locals across different industries connected in supplier-customer relationships. The increased productivity of local firms then is followed by higher wage paid for their workers. These explain the significant and positive sign of Vertical Spillover variable. This result confirms the findings of a previous study by Hoi \& Pomfret (2010), Du et al., (2012) and Pittiglio et al., (2012).

Moreover, Lipsey \& Sjoholm (2004) propos that regional factors might have an effect on the domestic firm's wage level. Responding to the wage level, employees will tend to move to firms with relatively higher wage. However, since Indonesia is considered as an archipelago country, their movement is limited among firms located in short distances, especially in the same province. Here, we use province as the geography proximity, assuming that workers do not move across different provinces.

Table 1 The effects of FDI inflow on domestic wages through horizontal and vertical spillovers

\begin{tabular}{|c|c|c|}
\hline Independent Variables & $\begin{array}{c}\text { Fixed } \\
\text { Effect } \\
(1)\end{array}$ & $\begin{array}{c}\text { Fixed } \\
\text { Effect } \\
(2)\end{array}$ \\
\hline \multirow{2}{*}{ Horizontal spillover } & 0.229 & \\
\hline & $(0.065)^{* * *}$ & \\
\hline \multirow{2}{*}{$\begin{array}{l}\text { Horizontal spillover- } \\
\text { region }\end{array}$} & & 0.444 \\
\hline & & $(0.046) * * *$ \\
\hline \multirow{2}{*}{ Vertical spillover } & 2.464 & 2.32 \\
\hline & $(0.526)^{* * *}$ & $(0.503)^{* * *}$ \\
\hline \multirow{2}{*}{ Business scale } & 4.498 & 4.621 \\
\hline & $(0.626)^{* * *}$ & $(0.625)^{* * *}$ \\
\hline \multirow{2}{*}{ Labour skill } & 0.033 & 0.036 \\
\hline & $(0.001)^{* * *}$ & $(0.002)^{* * *}$ \\
\hline \multirow{2}{*}{ Concentration level } & -0.009 & 0.0475 \\
\hline & $(0.079)$ & $(0.0781)$ \\
\hline \multirow{2}{*}{ Technology gap } & 0.0009 & 0.001 \\
\hline & $(0.0007)$ & $(0.0007)$ \\
\hline \multirow{2}{*}{ Capital intensity } & 0.0000 & 0.0000 \\
\hline & $(0.0000)$ & $(0.0000)$ \\
\hline Number of observations & 26143 & 26143 \\
\hline R-Squared & 0.04 & 0.04 \\
\hline
\end{tabular}

Note: Dependent variable: wages per employee paid by private domestic firms - in logarithm value

Source: Analytical result, 2019

To test this hypothesis, we examine another alternative measure, Horizontal spillover-region which indicates the employment created by foreign firms in the same industry and the same province. It means that we incorporate the role of geographical proximity in examining the effect of the presence of foreign firm on local firm's wage. Table 1 column 2 shows the result that the variable of horizontal region has also positive and significant coefficient. It indicates that FDI inflow increases the domestic firm's wage in the same industry within one province. In the other words, wage spillovers from foreign to local firm exists in both industrial and 
regional level. This finding confirms the result made by previous studies, Hoi \& Pomfret (2010) and Lipsey \& Sjoholm (2004).

The local-firm's wage level is also positively correlated with business scale and labour skill variables. Having larger business scale is associated with having higher capacity to pay higher wage level for the worker. In addition, when workers have high skill, the firm will tend to pay them higher wage. These results are also consistent with the findings from Hoi \& Pomfret (2010).

\subsection{The Effects of Sector Characteristics on Wage Spillovers}

Domestic firm characteristics may influence its ability to gain benefits from foreign firm's presence. In this study we focus on firm attributes in terms of technological intensity and firm size. Using the classification provided by United Nations Industrial Development Organization (UNIDO), we divide the sample firms into two categories based on its technological intensity ("UNIDO", n.d). We have 10 industries attributed as low technology intensity sector and 9 industries categorized to have medium and high technology intensity.

Table 2 Technological Intensity Classification

\begin{tabular}{|c|c|c|}
\hline Code & Industry & $\begin{array}{l}\text { Technology } \\
\text { intensity }\end{array}$ \\
\hline 10 & Manufacturing of food products & Low \\
\hline 11 & Manufacturing of food beverages & Low \\
\hline 12 & $\begin{array}{l}\text { Manufacturing of tobacco } \\
\text { products }\end{array}$ & Low \\
\hline 14 & Manufacturing of wearing apparel & Low \\
\hline 15 & $\begin{array}{l}\text { Manufacturing of leather and } \\
\text { related products }\end{array}$ & Low \\
\hline 16 & $\begin{array}{l}\text { Manufacturing of wood and of } \\
\text { products of wood and cork, } \\
\text { except furniture; woven from } \\
\text { bamboo, rattan, etc }\end{array}$ & Low \\
\hline 17 & $\begin{array}{l}\text { Manufacturing of paper and paper } \\
\text { products }\end{array}$ & Low \\
\hline 18 & $\begin{array}{l}\text { Printing and reproduction of } \\
\text { recorded media }\end{array}$ & Low \\
\hline 19 & $\begin{array}{l}\text { Manufacturing of coke and } \\
\text { refined petroleum products }\end{array}$ & Low \\
\hline 20 & $\begin{array}{l}\text { Manufacturing of chemicals and } \\
\text { chemical products }\end{array}$ & $\begin{array}{l}\text { Medium \& } \\
\text { High }\end{array}$ \\
\hline 21 & $\begin{array}{l}\text { Manufacturing of basic } \\
\text { pharmaceutical products and } \\
\text { pharmaceutical preparation }\end{array}$ & $\begin{array}{l}\text { Medium \& } \\
\text { High }\end{array}$ \\
\hline 22 & $\begin{array}{l}\text { Manufacturing of rubber and } \\
\text { plastics products }\end{array}$ & $\begin{array}{l}\text { Medium \& } \\
\text { High }\end{array}$ \\
\hline 23 & $\begin{array}{l}\text { Manufacturing of other non- } \\
\text { metallic mineral products }\end{array}$ & $\begin{array}{l}\text { Medium \& } \\
\text { High }\end{array}$ \\
\hline
\end{tabular}

\begin{tabular}{|c|l|c|}
\hline Code & \multicolumn{1}{|c|}{ Industry } & $\begin{array}{c}\text { Technology } \\
\text { intensity }\end{array}$ \\
\hline 25 & $\begin{array}{l}\text { Manufacturing of fabricated } \\
\text { metal products, except machinery } \\
\text { and equipment }\end{array}$ & Low \\
\hline 26 & $\begin{array}{l}\text { Manufacturing of computer, } \\
\text { electronic and optical products }\end{array}$ & $\begin{array}{c}\text { Medium \& } \\
\text { High }\end{array}$ \\
\hline 27 & $\begin{array}{l}\text { Manufacturing of electrical } \\
\text { equipment }\end{array}$ & $\begin{array}{c}\text { Medium \& } \\
\text { High }\end{array}$ \\
\hline 30 & $\begin{array}{l}\text { Manufacturing of other transport } \\
\text { equipment }\end{array}$ & $\begin{array}{c}\text { Medium \& } \\
\text { High }\end{array}$ \\
\hline 32 & $\begin{array}{l}\text { Other manufacturing except } \\
\text { medical and dental instruments }\end{array}$ & $\begin{array}{c}\text { Medium \& } \\
\text { High }\end{array}$ \\
\hline 33 & $\begin{array}{l}\text { Repair and installation of } \\
\text { machinery and equipment }\end{array}$ & $\begin{array}{c}\text { Medium \& } \\
\text { High }\end{array}$ \\
\hline
\end{tabular}

Source: "UNIDO", n.d

Table 2 shows that both groups, low-technology firm and medium \& high technology ones, gain wage spillover from the presence of foreign firms. However, horizontal effects only existsin the domestic firms with medium and high technologies. It means that the presence of foreign firms is not successful to force the low technological intensity local firm to increase their efficiency or to search new advanced technologies. The presence of foreign firms does not change the labour market of low technological intensity level firms.

Employing relatively low-skilled workers and using low technology, the wage level in low technological intensity firms might not be affected by the presence of multinational companies which typically engages high skilled workers and uses advanced technology. The locals might also have a different market sector with the multinationals. This basic difference then leads to significant wage differentials between them. Combined with the difference in their productivity, this then will provide a route for greater human capital formation in multinational firms with lower turnover. Consequently, there will a lack of wage spillover gained by domestic firms with low technological intensity. This finding is similar with the result of study by Pittiglio et al., (2012) and Aitken \& Harrison (1999).

Table 3 The effect of technology intensity level on wage spillovers

\begin{tabular}{|l|c|c|}
\hline \multirow{2}{*}{$\begin{array}{c}\text { Independent } \\
\text { Variables }\end{array}$} & \multicolumn{2}{|c|}{$\begin{array}{c}\text { Technology Intensity (Random } \\
\text { Effect) }\end{array}$} \\
\cline { 2 - 3 } & Low & $\begin{array}{c}\text { Medium and } \\
\text { High }\end{array}$ \\
\hline \multirow{2}{*}{ Horizontal spillover } & 0.435 & 0.518 \\
\cline { 2 - 3 } & $(0.083)$ & $(0.082)^{* * *}$ \\
\hline \multirow{2}{*}{ Vertical spillover } & 2.902 & 3.619 \\
\cline { 2 - 3 } & $(0.603)^{* * *}$ & $(0.767)^{* * *}$ \\
\hline \multirow{2}{*}{ Business scale } & 5.349 & 5.205 \\
\cline { 2 - 3 } & $(0.679)^{* * *}$ & $(0.892)^{* * *}$ \\
\hline
\end{tabular}




\begin{tabular}{|l|c|c|}
\hline \multirow{2}{*}{\begin{tabular}{c}
\multirow{2}{*}{$\begin{array}{c}\text { Independent } \\
\text { Variables }\end{array}$} \\
Labour skill
\end{tabular}} & \multicolumn{2}{|c|}{$\begin{array}{c}\text { Technology Intensity (Random } \\
\text { Effect) }\end{array}$} \\
\cline { 2 - 3 } & 0.028 & $\begin{array}{c}\text { Medium and } \\
\text { High }\end{array}$ \\
\cline { 2 - 3 } & $(0.002)^{* * *}$ & 0.373 \\
\hline \multirow{2}{*}{ Concentration level } & -0.318 & 0.742 \\
\cline { 2 - 3 } & $(0.094)^{* * *}$ & $(0.115)^{* * *}$ \\
\hline \multirow{2}{*}{ Technology gap } & -0.00007 & 0.006 \\
\cline { 2 - 3 } & $(0.001)$ & $(0.002)^{* * *}$ \\
\hline \multirow{2}{*}{ Capital intensity } & 0.092 & 0.098 \\
\cline { 2 - 3 } & $(0.005)^{* * *}$ & $(0.006)^{* * *}$ \\
\hline $\begin{array}{l}\text { Number of } \\
\text { observations }\end{array}$ & 17863 & 8379 \\
\hline R-Squared & 0.08 & 0.18 \\
\hline
\end{tabular}

Note: Dependent variable: wages per employee paid by private domestic firms - in logarithm value

Source: Analytical result, 2019

By contrast, medium and high technological intensity domestic companies empirically gain an increase in wage level through horizontal linkage. Bringing advanced level of technology and knowledge, the entry of multinational companies in domestic market makes the competition among medium and high technological intensity companies more intense. For local firms, increasing efficiency and productivity is a necessity to survive in the new highly competitive market. An increase in productivity will correlate with higher capacity to pay more wages. This finding is also consistent with the result of Hoi \& Pomfret (2010, p. 164).

On the other hand, FDI inflow vertically affects an increase in the wage level of domestic firms irrespective of the technological intensity level. The more multinational companies come in to the domestic market, the higher wage level will be paid by the local companies. This evidence suggests that the interaction between local and foreign firms in a supplier-customer relationship generates positive externalities for the domestics regardless of the technology level applied in the locals. This contact benefits the domestics to have higher productivity through imitating technologies and knowledge or employing higher skilled-workers due to training provided by the multinationals.

Other explanatory variables consist of the scale of business, skill level of the worker, concentration level of the industry, technology gap between the multinational company with the local one and capital intensity of the local firm are all significant in both column 1 and 2 regressions. Concentration level and technological gap are negatively correlated with domestic wage on low technological intensity firm. It means that high concentration level which means low competition level in the market correlates with low wage level. Similarly, wider technology gap between foreign and domestic firms imposes some difficulties for local firms to gain benefit from foreign presence. Consequently, the existence of multinational companies will reduce the local's productivity and their ability to pay higher wage.

However, these two independent variables are positively correlated with wage level in medium \& high technological intensity industry. Limited high skilled worker employed in this industry is the reason underlying this positive correlation. Typically, there are only a few number of firms in this type of industry which employ specific high skilled employees. The higher technology level needed in one industry, the less players in that industry will be. Computer, electronic and optical products industry is one example of high technological intensity with only few players within. They employ relatively high skilled software engineers that supplied limitedly in the market. To guarantee these limited workers do not move out to their competitors, the firms will tend to pay a high wage. So, in relatively high technology industry, higher concentration levels which mean lower degree of competition might correlate with a higher level of wage.

Moreover, the limited labour in this industry puts high value added of the individual workers. The workers relatively have high marginal productivity. When the technology gap between local and foreign firms within this industry widening, the value added of the workers will increase, resulting in an increase to their wage. So, in this type of industry, a widening technological gap correlates with an increase in the wage level. To some extent, this finding is similar with the result of study by Pittiglio et al., (2012).

Table 4 The effect of firm size on wage spillovers

\begin{tabular}{|l|c|c|}
\hline \multirow{2}{*}{$\begin{array}{c}\text { Independent } \\
\text { Variables }\end{array}$} & \multicolumn{2}{|c|}{ Firm Size (Random Effect) } \\
\cline { 2 - 3 } $\begin{array}{c}\text { Small \& Medium } \\
\text { Enterprises }\end{array}$ & $\begin{array}{c}\text { Large } \\
\text { Enterprises }\end{array}$ \\
\hline spillover & 0.165 & 0.512 \\
\hline \multirow{2}{*}{$\begin{array}{l}\text { Vertical } \\
\text { spillover }\end{array}$} & $(0.068)^{* *}$ & $(0.124)^{* * *}$ \\
\hline \multirow{2}{*}{\begin{tabular}{l} 
Business scale \\
\cline { 2 - 3 } Labour skill
\end{tabular}} & $(0.567)^{* * *}$ & 2.10 \\
\cline { 2 - 3 } & $(1.263)^{* * *}$ & $(0.94)^{* *}$ \\
\hline \multirow{2}{*}{$\begin{array}{l}\text { Concentration } \\
\text { level }\end{array}$} & 0.036 & 4.20 \\
\hline \multirow{2}{*}{\begin{tabular}{c} 
Technology gap \\
\cline { 2 - 3 }
\end{tabular}} & $(0.002)^{* * *}$ & $(0.574)^{* * *}$ \\
\cline { 2 - 3 } & 0.064 & -0.313 \\
\hline \multirow{2}{*}{ Capital intensity } & $(0.083)$ & $(0.153)^{*}$ \\
\cline { 2 - 3 } & $(0.001)^{* * *}$ & -0.30 \\
\hline $\begin{array}{l}\text { Number of } \\
\text { observations }\end{array}$ & 0.123 & $(0.007)^{* * *}$ \\
\hline
\end{tabular}




\begin{tabular}{|l|c|c|}
\hline \multirow{2}{*}{$\begin{array}{c}\text { Independent } \\
\text { Variables }\end{array}$} & \multicolumn{2}{|c|}{ Firm Size (Random Effect) } \\
\cline { 2 - 3 } & $\begin{array}{c}\text { Small \& Medium } \\
\text { Enterprises }\end{array}$ & $\begin{array}{c}\text { Large } \\
\text { Enterprises }\end{array}$ \\
\hline R-Squared & 0.10 & 0.18 \\
\hline
\end{tabular}

Note: Dependent variable: wages per employee paid by private domestic firms - in logarithm value

Source: Analytical result, 2019

Finally, we also use firm size as the other industrial heterogeneity proxy to account for the sectoral impact of the presence of foreign firms on domestic wages. Using the definition provided by Statistics Center Board of Indonesia, we divide the sample firms into two categories, small and medium enterprise, and large company. The small and medium firms is one which less than 100 workers, while large company is the firm employing minimum 100 employees.

Table 4 shows that horizontal and vertical linkage variables are positive and significant in both types of companies. FDI inflows increase the local's wage indifferent to the size of the firms. All other explanatory variables are also significant, except for concentration level variables in small and medium enterprises. Competition level in small \& medium-sized local firms does not give any significant impact on the wage level. The lack of need to compete with each other to acquire specified workers as occurring in large firm is the reason underlying this condition. Small and medium companies usually do not need any specialized high skilled worker, which is limitedly supplied in labour market, as large firms do. By contrast, for small \& medium firm's need, there are usually large amount of workers these company need in the labour market. So, there is no need for these firms to compete with each other to get workers they want. As a result, competition level will not give any significant effect on the wage level.

\section{Conclusion}

The empirical results provide strong evidence of wage spillovers existence from the foreign to the local firms both horizontally and vertically. Wage level of local firm is higher in the industries where a high level of FDI inflow exists (horizontal spillover). In line with this finding, the locals with high linkages to the multinationals will potentially gain productivity spillovers which then is followed by an increase of their ability to pay higher level of wage (vertical spillover).

Although vertical wage spillovers exists irrespective of the level of technology intensity, horizontal spillovers are not present in low technology intensity local firms. More competitive market generated by the presence of foreign firms does not sufficiently induce the low technological intensity local firms to increase their productivity. The large supply of expected workers needed by this type of firm might be the reason underlying for this result. Furthermore, horizontal and wage spillovers do exist in private domestic firms regardless the size of the firms.

\section{References}

Aitken, BJ., \& Harrison, AE. (1999). Do Domestic Firms Benefit from Direct Foreign Investment? Evidence from Venezuela. American Economic Review, 89(2), 605-618.

Blomström, Magnus., \& Kokko, A. (1998). Multinational corporations and spillovers. Journal Economic Surveys, 12(2), 1-31.

Driffield, N., \& Girma, S. (2000). Regional Foreign Direct Investment and Wage Spillovers: Plant Level Evidence from the U.K Electronics Industry. Oxford Bulletin of Economics and Statistics, 65(4), 453-474.

Du, Luosha., Ann Harrison., \& Gary H. Jefferson. (2012). esting for horizontal and vertical foreign investment spilloversin China, 1998-2007. Journal of Asian Economics, 23(3), 234-243.

Franco, C., \& Kozovska, K. (2011). Multinational Corporations and Local Firms in Emerging Economies. In E Rugraff, MW Hansen (Eds). Mutual productivity spillovers and regional clusters in Eastern Europe: Some Empirical Evidence (pp. 123-151). Amsterdam: Amsterdam University Press.

Gudaro, AM., Chhapra, IU., \& Sheikh, SA. (2012). Impact of foreign direct investment on economic growth: A case study of Pakistan. Journal of Management and Social Sciences, 8(2), 22-30.

Hoi, L.Q., \& Pomfret R. (2010). Foreign Direct Investment and Wage Spillovers in Vietnam. ASEAN Economic Bulletin, 27(2), 159-172.

Javorcik, B.S. (2004). Does foreign direct investment increase the productivity of domestic firms? In search of spillovers through backward linkages. The American Economic Review, 94(3), 605-627.

Lipsey, R.E., \& Sjöholm, F. (2004). FDI and Wage Spillovers in Indonesian Manufacturing. Review of World Economics, 140(2), 321-332.

Newman, C., Rand, J., Talbot, T., \& Trap F . (2015) Technology Transfers, Foreign Direct Investment and Productivity Spillovers. European Economic Review, 76 (issue C), 168-187.

Pham, T.H. (2009), Assessment of FDI Spillover Effects for the Case of Vietnam: A Survey of Micro-data Analyses. In Corbett, J. and S. Umezaki (eds.). Deepening East Asian Economic Integration. ERIA Research Project Report 2008-1, pp. 473495. Jakarta: ERIA.

Pittiglio, R., Reganati, F., \& Sica, E. (2012). Do Multinational Enterprises push up the Wages of Domestic Firms in the Italian Manufacturing 
Sector?. FIW Working Paper No. 99, FIW Research Centre International Economics, Vienna. Piyaareekul, N., \& Peridy, N. (2010). Foreign Direct Investment and Productivity Spillovers: the Experience of ASEAN Countries. Journal of Economic Integration, 25(2), 298-323.

Tomohara, A., \& Takii, S. (2011). Does globalization benefit developing countries? Effects of FDI on local wages. Journal of Policy Modeling, 33(3), 511-521.

UNIDO (United Nations Industrial Development Organization). (n.d). Classification of manufacturing sectors by technological intensity (ISIC Revision 4). Retrieved from https://stat.unido.org/content/focus/classificationof-manufacturing-sectors-by-technologicalintensity-\%2528isic-revision-

4\%2529; jsessionid=81E91A3863F23A4C317A63 F8BE848C7B 